\title{
THE TEACHING OF HUMAN ANATOMY IN BRAZIL: THE REALITY
} OF NORTHEAST BRAZIL

Polieria Santos Oliveira ${ }^{1}$, Jalles Dantas de Lucena ${ }^{2}$, Francisco Rafael Oliveira da Silva ${ }^{2}$, Katarina Maria Brasileiro Leal ${ }^{3}$, Jonas Nogueira Ferreira a Maciel Gusmão ${ }^{2}$, Osvaldo Pereira da Costa Sobrinho ${ }^{3}$, João Erivan Façanha Barreto ${ }^{3}$, Deiziane Viana da Silva Costa ${ }^{2}$, Ariel Gustavo Scafuri ${ }^{2,3}$, Delane Viana Gondim ${ }^{2,3}$, Gilberto Santos Cerqueira ${ }^{2,3}$.

${ }^{1}$ Faculty Vale do Salgado Ceara, Brazil.

${ }^{2}$ Faculty of Medicine, Post-Graduate Program in Morphofunctional Sciences, Federal University of Ceara, Fortaleza, Ceara, Brazil.

${ }^{3}$ Department of Morphology, Federal University of Ceara, Fortaleza, Ceara, Brazil.

\section{ABSTRACT}

Background: This study aimed to investigate student perceptions regarding the teaching and learning process in the subject of Human Anatomy, an integral part of the Nursing course at the university studied.

Materials and Methods: This is a quantitative study of a descriptive, exploratory nature conducted at a College in the Northeast region of Ceara state. It was performed with ninety-two students from of the courses nursing, who were all enrolled for the discipline concerned and attended the Human Anatomy Laboratory. Semi-structured interviews yielded the qualitative data.

Results: It was found that $70.65 \%$ of the interviewees were female. It was observed that $28.26 \%$ of the interviewees reported that the workload was insufficient, while $65.21 \%$ reported that the corpse study would be indispensable for anatomical practice. The main teaching practice used was passive methodologies $39.41 \%$. During the practical classes the main form was to use a mannequin $93.4 \%$. It was verified that $83.69 \%$ reported the importance of the elaboration of an image bank for Anatomy study.

Conclusions: The teaching of Human Anatomy needs to be rethought in order to meet the expectations of this new and current moment. In the attempt to introduce practical classes with cadaver and anatomical pieces which would facilitate the process of teaching-learning in the discipline of Anatomy.

KEY WORDS: Anatomy, Education, Morphology, Learning Anatomy.

Address for Correspondence: Prof. Dr. Gilberto Santos Cerqueira, Department of Morphology Federal University of Ceara, Street Delmiro de Farias s/n - Campus Porangabussu - Ceara Brazil. CEP: 64.204-035. Phone: +55 (85) 3366-8497. E-Mail: giufarmacia@hotmail.com

\section{Access this Article online}

\section{Quick Response code}

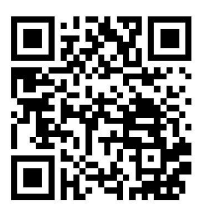

DOI: $10.16965 /$ ijar.2017.423

Web site: International Journal of Anatomy and Research ISSN 2321-4287

www.ijmhr.org/ijar.htm

Received: 17 Aug 2017

Peer Review: 17 Aug 2017

Revised: None
Accepted: 03 Oct 2017

Published (O): 01 Nov 2017

Published (P): 01 Nov 2017

\section{INTRODUCTION}

Anatomy remains a cornerstone of health science education despite challenges that have seen a significant reduction in contact hours over recent decades $[1,2]$.

Human Anatomy is an essential part of the first years' curriculum of health science schools. By learning gross Anatomy, students get their first 
"impression" about the structure of the human body, which is the basis for understanding pathological and clinical issues [3, 4].

Higher education in health, in general, has been criticized in recent decades. In many countries there has been growing questioning by society of the capacity of higher education institutions to fulfill the general objectives of their programs, which should be to develop the students' intellectual potential, encourage the capacity for analysis, Critical problem-solving skills and build critical problem-solving skills, as well as establish a creative and inquiring approach $[5,6]$. The Human Anatomy was and undoubtedly remains a discipline for the understanding of the Morphofunctional structures of the human body, and knowledge of the structure of organs and their functions, being obligatory for the courses of health science of the World. The programs generally focus on aspects of cardiovascular morphology, endocrine, gastrointestinal, genitourinary, immune, metabolic, musculoskeletal, nervous, reproductive, respiratory and surface Anatomy [7].

In this context the teaching of Anatomy carried out in Brazilian Universities, in addition to theoretical classes, practical classes are given using anatomical pieces: whole cadavers or their parts, prepared and stored in special vats in formalin solution $10 \%$. Among the courses that study the Human Anatomy are: Medicine, Dentistry, Speech Therapy, Physical Education, Pharmacy, Biomedicine, Physiotherapy, Occupational Therapy, Nursing, Nutrition, Speech Therapy, Dance, Biology among others [8].

The teaching of Anatomy has gradually evolved, with new techniques for preserving cadavers, methods of dissection and technological advancement and the evolution of didactic methods $[9,10,11]$. Therefore, the corpse ends up being a material whose existence is essential, since it allows the focus of each organ or part of them. The knowledge of these consists in the primordial base to the exercise of the future clinical practice and mainly surgical of the students [12]. However, after these changes occurred in the methodology of practical classes in this period, no significant change in teaching was perceived until today [13]. However, the teaching practice used in this discipline dem- onstrates traditional banking education. Thus, the pedagogical practices, carried out in its interior, are a reflection of and reflect on society, mirroring the complexity of social dynamics and human interaction.

In Brazil, in the last four years, several health courses have been opened for a policy that is unrestrained and deliberate by the Ministry of Education, which diminishes the quality of Anatomy disciplines in the city outside the large centers. In addition, teaching practices were compromised by the inadequate use of teaching methodologies and the lack of corpses for all higher education institutions in the interior of the state.

Knowing these practices and unveiling them is fundamental to the awareness and decisive for actions to be taken to promote improvement in the teaching and learning process of Anatomy. Based on these premises the objective of our work was to investigate the conditions of Human Anatomy teaching in a College of Nursing in Northeast Brazil, Ceara.

\section{MATERIALS AND METHODS}

We conducted a cross-sectional study of quantitative and qualitative nature involving the nursing students of a higher education institution in the state Ceara, Brazil. The study population consisted of 180 nursing students, and the sample consisted of 92 students. The instrument using for data collection was a semi-structure questionnaire, containing easyto-understand questions and previously tested in a pilot study. This instrument was based on the work of Neves et al. [14], modified, containing elements for the characterization of the participants, as well as objective and subjective questions.

Through assessment tool I, socio-demographic information such as gender, age and current occupation were searched. The students answered questions related to the teaching Anatomy.

During the research the questionnaire assessed the level of technical knowledge these students possessed in terms in relation to the teaching and learning process of Human Anatomy. True and false statements were presented to the students. The scale used in this tool consisted of a 
five score (0-5); the lowest number stands for "absolutely false" and the highest option means "absolutely true". For the false statements, there was an inversion of the values for the calculation of the final score, e.g., if a student assigned a score of 1 to a false assertion, which was the correct answer; the score was then converted to five points.

During the study students and researchers evaluated the curriculum of the course where they evaluated the pedagogical political project, the syllabus of the discipline and the anatomy teaching plan.

The survey was conducted with students of nursing through the stratified probabilistic method, in which the calculation of the sample was designed considering a confidence level of $95 \%$ and a 5\% sample error. For this study, data was gathered from 92 students. The assessment tools were administered after all subjects had fully agreed and signed the consent form.

To carry out descriptive statistical analysis, data were analyzed by the Mann-Whitney test multiple comparisons test using GraphPad Prism, version 6 (GraphPad Software Inc., San Diego, CA) and where considered significant when $P<0.05$.

The research was approved by the Ethics Committee of the Facultty Integradas de Patos, Paraiba, Protocol number CEP/FIP no 0494/2010.. Prior to each interview with the students, they were asked to sign a Free Consent and Understanding Agreement (FCUA).

\section{RESULTS}

It was observed that the majority of the female subjects (70.65\%), in the age range between 17 and 50 years. Most of them (93.4\%) lived in the interior city of the state, and most of them were students without previous higher education and nursing technicians seeking qualification in higher education. The average age of the student was $25.46 \pm 1.05$, demonstrating a young student body. It was observed that there is no statistically significant difference between the mean age of the students' sexes ( $p$ 0.4691).

It was verified that most of the classes were taught with $100 \%$ traditional methodologies and lack of active methodologies. Of the $38.28 \%$ of the classes were taught using plastic manikins, $29.14 \%$ theoretical only, $16 \%$ seminars, $6.29 \%$ scientific debates, $5.71 \%$ articles reading, $2.86 \%$ discussion of clinical cases and $1.72 \%$ others methods.

With regard to the resources used in the practical classes, $93.47 \%$ of the interviewees used didactic puppet classes, while $6.53 \%$ used other resources. It was verified that $100 \%$ of the interviewees did not have practical classes with cadavers in the college, and that the only contact with the corpses was a single visit to the laboratory of Human Anatomy of another public institution of education. It was also verified that $65.21 \%$ reported that the corpse study would be essential for anatomical practice.

With regard to suggestions for improvement of the Anatomy discipline, we found that $42.42 \%$ suggested the use of cadavers, $21.97 \%$ increase the workload, $19.7 \%$ suggested improvements in the laboratory, $15.91 \%$ increase the number of practical classes. It was verified that $83.69 \%$ reported the importance of the elaboration of an image bank for Anatomy study. It was observed that $28.26 \%$ of the interviewees reported that their workload was insufficient. It was verified the need to carry out a curricular reform with the need to increase the workload and implementation of integrated education with the basic science and the clinic, in order to increase the anatomical retention of knowledge and better distribution of the workload. These adjustments should be made in the pedagogical political project and in the course syllabus. These meetings should take place in conjunction with teachers at the base and the clinical cycle for a better discussion.

\begin{tabular}{c|c|c|c|}
\cline { 2 - 4 } Table 1: Data & Gender & $\mathbf{n}$ & $\%$ \\
\cline { 2 - 4 } demographics & Male & 27 & 29.35 \\
\cline { 2 - 4 } of interviewed. & Female & 65 & 70.65 \\
\cline { 2 - 4 } & Total & $\mathbf{9 2}$ & $\mathbf{1 0 0}$ \\
\hline
\end{tabular}

Table 2: Teaching methodologies used in the discipline of Human Anatomy.

\begin{tabular}{|c|c|c|}
\hline Methodological resource & $\mathrm{n}$ & $\%$ \\
\hline Practice class without plastic mannequin & 67 & 38.28 \\
\hline Theoretical class & 51 & 29.14 \\
\hline Seminary & 28 & 16 \\
\hline Debate & 11 & 6.29 \\
\hline Reading article & 10 & 5.71 \\
\hline Case discussion & 5 & 2.86 \\
\hline Others & 3 & 1.72 \\
\hline Total & $\mathbf{1 7 5}$ & $\mathbf{1 0 0}$ \\
\hline
\end{tabular}


Table 3: Didactic resources of practical classes.

\begin{tabular}{|c|c|c|}
\hline Resources & $\mathbf{n}$ & $\%$ \\
\hline Classes with plastic mannequin & 86 & 93.47 \\
\hline Others resources & 6 & 6.53 \\
\hline Total & $\mathbf{9 2}$ & $\mathbf{1 0 0}$ \\
\hline
\end{tabular}

Table 4: Suggestions for improvement in Anatomy teaching.

\begin{tabular}{|c|c|c|}
\hline Suggestions & $\mathrm{n}$ & $\%$ \\
\hline Use of cadavers and anatomical pieces & 56 & 42.42 \\
\hline Increase of the theoretical hours & 29 & 21.97 \\
\hline Improve the structure of laboratories & 26 & 19.7 \\
\hline More practical classes & 21 & 15.91 \\
\hline Total & 132 & 100 \\
\hline
\end{tabular}

\section{DISCUSSION}

Anatomy education is facing challenges mainly due to reduced curriculum time and lack of cadavers. In order to overcome these constraints, there is a need to introduce technology-assisted self-regulated learning methods such as blended learning along with the traditional face-to-face classroom teaching method [15]. In the classroom, it is necessary to implement innovative teaching methodologies in order to promote meaningful learning.

The results of this study, illustrated that student participation in the journaling process of change in the form of current teaching is essential for improving the teaching of Anatomy being the main source of feedback in the process of teaching and learning.

Our results corroborate with studies carried out in Brazil [16], where we verified the insistence on the unique use of traditional methodology, the non-use of active methodologies, allied to the lack of cadaver, contribute to the promotion of mechanical learning and lack of affinity of some students with Anatomy. Thus, the active methodology becomes an important tool in the teaching and learning of Anatomy.

Chickering and Gamson [17] included the use of active methodologies among the seven principles for good educational practice. These authors draw attention to activities involving cooperation, interaction, diversity and responsibility of learners, especially in small groups, thus favoring meaningful learning.

The Anatomy laboratory is an ideal setting for faculty/student interaction and provides invalua ble opportunities for active learning and reflection on anatomical knowledge [18].

The possibilities for developing active teachinglearning methodologies are manifold, such as the problem-based learning strategy (PBL), team-based learning (TBL), the circle of culture among others [19]. The difficulty of the teacher to implant the active methodologies in Anatomy teaching is lack of training, combined with the lack of human resources to implement these methods. The teaching of Human Anatomy, like that of any course, requires constant revision and analysis to determine the teaching tools and approaches that best suit the learning process [20]. In recent times, there has been a reduction in traditional, cadaver-based, Anatomy teaching, in some cases driven by a shift towards an integrated and/or system-based curriculum $[21,22]$.

With regard to the teaching methodologies used, it was observed that $38.28 \%$ of the interviewees reported that they had practical classes, followed by $29.14 \%$ of the interviewees who had the traditional lecture or "Bank Education" criticized by Paulo Freire. In traditional education or banking education, what is important is the transmission of the contents by the teacher, which is deposited in the head of the students, a priori devoid of any knowledge [23-25].

"Banking education aims to maintain the division between those who know and those who do not know, between the oppressed and oppressors. It denies dialogue, while problem atizing education is based precisely on the dialectic-dialectic relationship between educator and educator Both learn together [23]."

Banking education is a bourgeois pedagogy, comparing learners to mere custodians of a baggage of knowledge that must be assimilated without discussion. Paradoxically, this modality of education would have as an objective not to equalize the knowledge between educator and educating, but rather to "maintain the division between those who know and those who do not know, between the oppressed and the oppressors." The educator is necessarily an oppressor [25]. Our data corroborate the study of Rozendo et al. [19] regarding teaching methods and the most used teaching resources, which observed in their study that (86.2\%) of teachers affirmed 
to make use of the lecture as teaching method followed by case discussion ( $48.3 \%$ ), laboratory practice class $(41.4 \%)$, clinical practice class (34.5\%) and seminary (27.6\%).

According to Arruda and Sousa [26], it is that the teaching of Anatomy has been effected by reproductive practices, in which the apprehension of knowledge is merely mechanical, and that assessments are usually organized in two stages: a theoretical test, centered in the definition of functions of different organs and systems, and another practice, in which students, in most cases, have to identify anatomical structures previously marked. In the specific case of this discipline, mechanical learning is necessary, but simply memorizing the names of anatomical structures is not enough. It is necessary to follow the continuum between mechanical and meaningful learning so that students, future professionals, can understand why that form and position.

Another important tool in the process of teaching and learning Anatomy is the technique of bodypainting that has great potential to use, as well as classic methods to teach Human and Veterinary Anatomy, thus being an important methodology to replace traditional education and lack of cadaver [27, 28].

The cadaveric material is the first choice tool for the teaching and learning process, but there are challenges to reintegrating the most effective teaching and learning tools while maintaining the beneficial values of orthodox dissection $[29,30]$.

The result of this study demonstrates only the use of synthetic pieces, this difficulty is currently infirm in Brazil for three reasons excess of higher courses, without cadaver for all universities, advances in forensic medicine in the identification of indigent bodies, which was the main sources of donation for the laboratories and serious cultural problem in the Northeast of Brazil where by religious factors the population do not donate their bodies for studies. In several countries the discipline of Anatomy has been suffering with the reduction of the hourly load which has been compromising the teaching of the contents, making what the teaching of this discipline is superficial and forcing often the students of the last semester back to study
Anatomy on account of disability Learning in the initial series.

In our studies, the hourly loads of 100 hours analyzed through the menu during the study corroborate with the workload of most of the Brazilian universities. Often, in an attempt to solve the problems, traditional actions of little effectiveness are carried out, for example the increase of the workload. In Brazil, health courses tend to have disciplines whose hours are very high, divided between theory and practice and sometimes the results obtained are not always satisfactory, and it is often proposed to increase the workload to solve the difficulties [19].

The human anatomy forms the basis for the health sciences so its place in the curriculum deserves special attention. The results of this survey should not be overly interpreted, but are useful in discussing how to modify the Anatomy curriculum. A comparison of such data between countries would have to Differences in legislation, number of students, admission criteria, etc., as partially summarized for South America, Europe and the United States [31]. Our data corroborate with studies conducted in the Middle East and other regions in Brazil where the authors verified the need to carry out the curricular reform to promote improvements in the teaching and learning process of anatomy [31]. It was investigated among the students about the importance of creating anatomical image banks for Anatomy teaching, where we verified that $83.69 \%$ of the students stated that the creation of this bank would facilitate the learning of Anatomy. Our studies corroborate with studies by Neves [23] that verified that $98 \%$ of the interviewees affirmed the importance of elaborating a 3D image bank. 3D model is a useful tool for teaching Anatomy concepts being a practical tool of low cost for use in teaching Anatomy [32].

\section{CONCLUSION}

Therefore, it can be concluded that the teaching of Anatomy in the higher education institution requires the introduction of new teaching methodologies in order to facilitate the process of teaching learning, a good example of this would be the introduction of active methodology as the problematizing methodology, 
however for this to take place it becomes necessary to carry out the teaches qualification in the use of active methodology.

With these reflections that propose that we rethink the teaching of Anatomy in the Brazilian Northeast. The introduction of active methodologies can be a way to produce meaningful learning of Anatomy, thus reducing mechanical learning. In addition, the introduction of information technology would be another strategy to improve the quality of classes.

3D model is a useful tool for teaching Anatomy concepts, without the need to resort to written texts. It is a practical tool of low cost for use in the process of teaching and learning.

It is believed that this work can contribute with the reflections to introduce innovation of teaching in Anatomy, from a virtual educational proposal and creation of a program of body donation to university, aiming to provide practical classes with cadaver and dissection and thus motivating the student to arouse a greater interest in Anatomy.

\section{ACKNOWLEDGEMENTS}

The authors thank the allied health science students and College Vale do Salgado who participated in this study for sharing their personal experiences

\section{Conflicts of Interests: None}

\section{REFERENCES}

[1]. Halliday N, O'Donoghue D, Klump KE, et al. Human structure in six and one-half weeks: One approach to providing foundational anatomical competency in an era of compressed medical school anatomy curricula. Anat Sci Educ. 2015; 8(2): 149-157, doi: 10.1002/ase.1476, indexed in Pubmed: 24996159.

[2]. Barry DS, Marzouk F, Chulak-Oglu K, et al. Anatomy education for the YouTube generation. Anat Sci Educ. 2016; 9(1): 90-96, doi: 10.1002/ase.1550, indexed in Pubmed: 26061143.

[3]. Papa V, Vaccarezza M. Teaching anatomy in the XXI century: new aspects and pitfalls. Sci World J. 2013; 2013: $1-5$, doi: $10.1155 / 2013 / 310348$, indexed in Pubmed: 24367240.

[4]. Alsaid B. Slide shows vs graphic tablet live drawing for anatomy teaching. Morphologie. 2016; 100(331): 210-215, doi: 10.1016/j.morpho.2016.05.003, indexed in Pubmed: 27363311.

[5]. Mamede S, Penaforte JC, Schmidt HG, Caprara A, Tomaz JBC, Sá HL. Aprendizagem baseada em problemas: anatomia de uma nova abordagem educacional. 1a ed. Fortaleza: Hucitec/Escola de Saúde Pública 2001.

[6]. Costa NMSC. Teacher training for nutrition professors: a tacitly accepted omission?. Rev Nutr. 2009; 22(1): 97-104, doi: 10.1590/S1415-52732009000 100009.

[7]. Heylings DJA. Anatomy 1999-2000: The curriculum, who teaches it and how?. Med Educ. 2002; 36(8): 702-710, doi: 10.1046/j.1365-2923.2002.01272.x, indexed in Pubmed: 12191052.

[8]. Biassuto SN, Caussa LI, Criado del Río LE. Teaching anatomy: cadavers vs. computers?. Ann Anat. 2006; 188(2): 187-190, doi: 10.1016/j.aanat.2005.07.007, indexed in Pubmed: 16551018.

[9]. Johnson EO, Charchanti AV, Troupis TG. Modernization of an anatomy class: from conceptualization to implementation: a case for integrated multimodal - multidisciplinary teaching. Anat Sci Educ. 2012; 5(6): 354-366, doi: 10.1002/ase.1296, indexed in Pubmed: 22730175.

[10]. Lewis TL, Burnett B, Tunstall RG, et al. Complementing Anatomy Education Using Three-Dimensional Anatomy Mobile Software Applications on Tablet Computers. Clin Anat. 2014; 27(3): 313-320, doi: 10.1002/ca.22256, indexed in Pubmed: 23661327.

[11]. Moro C, Štromberga Z, Raikos A, et al. The effectiveness of virtual and augmented reality in health sciences and medical anatomy. Anat Sci Educ. 2017; (in press), doi: 10.1002/ase.1696, indexed in Pubmed: 28419750.

[12]. Dissabandara LO, Nirthanan SN, Khoo TK, et al. Role of cadaveric dissections in modern medical curricula: a study on student perceptions. Anat Cell Biol. 2015; 48(3): 205-212, doi: 10.5115/ acb.2015.48.3.205, indexed in Pubmed: 26417481.

[13]. Salbego C, Oliveira EMD, Silva MAR, et al. Student Perceptions of Teaching and Learning Human Anatomy. Rev bras educ med. 2015; 39(1): 23-31, doi: 10.1590/1981-52712015v39n1e00732014.

[14]. Neves MVS. Uma nova proposta no ensino de Anatomia Humana: desafios e novas perspectivas. Volta Redonda: Rio de Janeiro 2010.

[15]. Kharb P, Samanta PP. Blended learning approach for teaching and learning anatomy: Students' and teachers' perspective. J Anat Soc India. 2016; 65(1): 43-47, doi: 10.1016/j.jasi.2016.06.001.

[16]. Costa GBF, Costa GBF, Lins CCSA. The Corpse in the Teaching of Human Anatomy: a Methodological and Bioethics Overview. Rev bras educ med. 2012; 36(3): 369-373, doi: 10.1590/S0100-55022012000500 0 11.

[17]. Chickering AW, Gamson ZF. Seven Principles for Good Practice in Undergraduate Education. AAHE Bull. 1987; 3: 3-7.

[18]. Lazarus L, Sookrajh R, Satyapal KS. Reflective Journals: Unmasking student perceptions of anatomical education. Folia Morphol. 2017; 1-27 (in press), doi: 10.5603/FM.a2017.0019, indexed in Pubmed: 28248411.

[19]. Rozendo CA, Casagrande LDR, Schneider JF, et al. An analysis of the teaching practices of faculties in 
the health area. Rev Latino-Am Enfermagem. 1999; 7(2): 15-23, doi: 10.1590/S0104-11691999 000 200003.

[20]. Moxham BJ, Plaisant O. Perception of medical students towards the clinical relevance of anatomy. Clin Anat. 2007; 20(5): 560-564, doi: 10.1002/ ca.20453, indexed in Pubmed: 17149736.

[21]. Drake RL, McBride JM, Lachman N, et al. Medical education in the anatomical sciences: the winds of change continue to blow. Anat Sci Educ. 2009; 2(6): 253-259, doi: 10.1002/ase.117, indexed in Pubmed: 19890982.

[22]. Tibrewal S. The anatomy knowledge of surgical trainees: the trainer's view. Ann R Coll Surg Engl. 2006; 88: 240-242, doi: 10.1308/147363506X113857.

[23]. Freire P. Educação como prática da liberdade. 5. ed. Paz e Terra, Rio de Janeiro 1975.

[24]. Freire P. Educação e mudança. 15. ed. Paz e Terra, Rio de Janeiro 1989.

[25]. Freire P. Pedagogia do oprimido. 17. ed. Paz e Terra, Rio de Janeiro 1987.

[26]. Arruda RM, Sousa CRA. Students' Theoretical-Practical Harnessing of the Subject of Human Anatomy in Physiotherapy Courses. Rev bras educ med. 2014; 38(1): 65-71, doi: 10.1590/S0100-55022014000 100009.

[27]. Senos R, Ribeiro MS, Martins Kde S, et al. Acceptance of the bodypainting as supportive method to learn the surface locomotor apparatus anatomy of the horse. Folia Morphol. 2015; 74(4): 503-507, doi: 10.5603/FM.2015.0023, indexed in Pubmed: 26620513.
[28]. Goulart L, Remijo KM, Silva AA, et al. Body painting as a methodological resource for the teaching of human anatomy for medical students of the Federal University of Amazonas, Brazil. EFDeportes. 2015; 20(209): 1-5.

[29]. Sugand K, Abrahams P, Khurana A. The anatomy of anatomy: a review for its modernization. Anat Sci Educ. 2010; 3(2): 83-93, doi: 10.1002/ase.139, indexed in Pubmed: 20205265.

[30]. Portugal HSP, Palma PCR, Fraga R, et al. A Synthetic Three-Dimensional Pelvic Model as an Effective Didactic Tool Compared to Cadaveric Pelvis. Rev bras educ med. 2011; 35(4): 502-506, doi: 10.1590/ S0100-55022011000400009.

[31]. Kaimkhani, ZA, Ahmed, M, Al-Fayez, M, Zafar, M, Javaid, $A$. Does the existing traditional undergraduate Anatomy curriculum satisfy the senior medical students? A retrospective evaluation. Einstein. 2009; 7(3 Pt 1):341-6. http://apps.einstein.br/ revista/arquivos/PDF/1433-Einstein\%20v7n3p3416_port.pdf

[32]. Rivas RDA. 3D didactic model and useful guide of the semicircular conduct. Braz j otorhinolaryngol. 2011; 77(3): 303-307, doi: 10.1590/S180886942011000300006 .

\section{How to cite this article:}

Polieria Santos Oliveira, Jalles Dantas de Lucena, Francisco Rafael Oliveira da Silva, Katarina Maria Brasileiro Leal, Jonas Nogueira Ferreira a Maciel Gusmão, Osvaldo Pereira da Costa Sobrinho, João Erivan Façanha Barreto, Deiziane Viana da Silva Costa, Ariel Gustavo Scafuri, Delane Viana Gondim, Gilberto Santos Cerqueira. THE TEACHING OF HUMAN ANATOMY IN BRAZIL: THE REALITY OF NORTHEAST BRAZIL. Int J Anat Res 2017;5(4.2):4623-4629. DOI: 10.16965/ijar.2017.423 